\title{
Effects of Hormones on Post-Implantation Mouse Embryos in Vitro.
}

\author{
I. Insulin
}

\author{
D.L. FISHER \\ Department of Anatomy, The University of Michigan, Ann Arbor, Michigan \\ 48109
}

\begin{abstract}
Day 9 mouse embryos were cultured in $50 \%$ fetal calf serum and $50 \%$ Waymouth's medium supplemented with various amounts of insulin. Unmodified medium contained approximately $25 \%$ of the normal adult mouse blood insulin. The addition of 0.1 to $1.0 \mu \mathrm{g}$ insulin $/ \mathrm{ml}$ to Waymouth's medium was most beneficial to in vitro development. There was a statistically significant increase in protein synthesis, RNA content, glucose utilization, and heart rate, as well as a significant decrease in pericardial edema. DNA synthesis was unchanged or slightly decreased. The optimal amount of added insulin $(0.05 \mu \mathrm{g} / \mathrm{ml})$ is much higher than the normal circulating levels in adult mice.
\end{abstract}

The actions of insulin on adult tissues are widely observed in the metabolism of carbohydrates, fats, proteins, and nucleic acids (Review of literature by Krahl, '61; Manchester, '65, '70). Presumably, since it can also pass through the placenta, insulin may also affect the metabolic activity of embryonic or fetal tissues with which it comes into contact. In vitro with the serum comprising only $50 \%$ of the culture medium, the insulin levels in the medium would be well below those to which the fetus is normally exposed. The present study was designed to monitor the effects of changes of insulin concentration in the developing mouse embryo.

\section{MATERIALS AND METHODS}

\section{Embryo collection and cultivation}

Virgin female mice, strain $120 \mathrm{SvSl}$, were housed, five females per male, and given water and a commercial mouse diet ad libitum. A 15-hour day cycle was used. The day of finding the copulation plug was designated day 0 of pregnancy. Embryos were collected on day 9 and dissected according to the method of New and Coppola ('77). At this time, the embryos are at the 9 to 13 somite stage and are beginning to rotate from a dorsiflexed to a ventroflexed position. The neural tube is not yet closed and limb buds are absent. The visceral yolk sac circulation is not evident.

Cultivation conditions followed the method of Kochhar ('75) using 50\% Waymouth's medium (GIBCO) and $50 \%$ fetal calf serum
(GIBCO). The Waymouth's medium was supplemented with $5,000 \mathrm{U} / \mathrm{A}$ penicillin, 5,000 $\mu \mathrm{g} / \mathrm{l}$ streptomycin, $4 \mathrm{~g} / \mathrm{l}$ RIA insulin negative Albumin (Sigma), and 0, 0.05, 0.1, 0.5, 1, 5, or $10 \mu \mathrm{g} / \mathrm{ml}$ sodium insulin. ${ }^{1}$ Embryos were placed in $10 \mathrm{ml}$ screw cap plastic test tubes containing $1.5 \mathrm{ml}$ of medium maintained at $37^{\circ} \mathrm{C}$ and rotated on a mechanical rotator at 30-40 RPM. The gassing sequence used was that suggested by New and Coppola ('77), beginning with $10 \%$ $\mathrm{O}_{2}, 5 \% \mathrm{CO}_{2}$, and $85 \%$ nitrogen. The $\mathrm{O}_{2} \%$ was increased every 12 hours to $20 \%, 50 \%, 80 \%$, and finally $95 \%$ (if warranted). Nitrogen was decreased concomitantly. The $5 \% \mathrm{CO}_{2}$ was held constant for stabilization of $\mathrm{pH}$. The embryos were transferred to fresh medium after 24 hours, and cultivation was normally terminated after 36 hours, although some embryos were allowed to continue 12 hours longer. At least five separate experiments, with a total of no less than 35 embryos in each, were made for each dose of insulin. Embryos cultivated without exogenous insulin served as controls. A radio-immunoassay was used to measure insulin in all media used and to measure the normal circulating level of insulin in this strain of mouse.

\section{Analytic methods}

1. Gross anatomical parameters. At termination of cultivation, at 24 or 36 hours, the following developmental parameters were analyzed

${ }^{1}$ Gift of E]i Lilly and Company. Lot. \#IDG04-94-193. 
in treated and nontreated embryos: growth in size and shape; somite number; closure of the anterior neuropore; ventroflexion; development of anterior limb buds; establishment of visceral yolk sac circulation; development of the allantoic and amniotic sacs; development of the heart; heart rate; and development of the central nervous system.

2. Protein analysis. Analysis followed the method of Lowry, et al. ('51). At 0 and 24 hours the homogenate of one embryo was used for analysis. At 36 hours the homogenate could be diluted by one-half.

3. DNA and RNA analysis. Analysis was by the ethidium bromide fluorometric technic of Prasad, et al. ('72), as modified by Dr. E. Ritter (personal communication, '78). The spectrophotofluorometer excitation wave length was 365 $\mu \mathrm{m}$ and emission wave length was $590 \mu \mathrm{m}$. Analysis was made at 0,24, and/or 36 hours for each experiment.

4. Glucose analysis. Glucose was determined on the cultivation medium at 0,24 , and 36 hours. The method of Marks ('59), as modified by Cockroft and Coppola ('77), is a simple, accurate, and rapid colormetric method for the determination of glucose in blood or serum using glucose-oxidase and peroxidase.

5. Statistical analysis. The "student t" test was used for comparisons between the treated and non-treated embryos. An analysis of variance and Dunnett's " $\mathrm{d}$ " statistic were also compared. The correlation coefficients of linearized standard curves were all greater than $r=0.98$.

\section{RESULTS}

Radioimmunoassay of the fetal calf serum used revealed insulin concentrations with a range of $29-46 \times 10^{-5} \mu \mathrm{g} / \mathrm{ml}$ and a mean of $38 \pm$ $2 \times 10^{-5} \mu \mathrm{g} / \mathrm{ml}$. This did not differ significantly from that reported by Esber, et al., ('73). Serum samples from adult $129 \mathrm{SvSl}$ mice had insulin concentrations of $54-82 \times 10^{-5} \mu \mathrm{g} / \mathrm{ml}$ with a mean of $71 \pm 8 \times 10^{-5} \mu \mathrm{g} / \mathrm{ml}$.

Preliminary experiments showed that, in order to demonstrate a beneficial effect of insulin, it was necessary to add to the medium a concentration of insulin 700 times in excess of that found in the serum of an adult $129 \mathrm{SvSl}$ mouse. However, some tissue culture media have even higher concentrations of insulin such as Trowell's T8 medium containing $50 \mu \mathrm{g}$ insulin $/ \mathrm{ml}$.

\section{Biochemical analysis}

Glucose utilization was significantly elevated above control values in media containing between 0.1 and $1 \mu \mathrm{g}$ insulin $/ \mathrm{ml}$. Maximum utilization in medium containing $0.5 \mu \mathrm{g}$ insulin $/ \mathrm{ml}$ (Fig. 1) was $843 \pm 57 \mu \mathrm{g}$ glucose/ embryo after 24 hours and $1561 \pm 140 \mu \mathrm{g}$ glucose/embryo after 36 hours.

A significant increase in protein synthesis was found at 36 hours cultivation in media containing between 0.05 and $0.5 \mu \mathrm{g}$ insulin $/ \mathrm{ml}$. The maximum response was $143.7 \pm 4.0 \mu \mathrm{g}$ protein/embryo at $0.5 \mu \mathrm{g}$ insulin/ml (Fig. 2). Even though the addition of insulin increased embryonic protein production significantly above the controls, embryos of comparable age developing in vivo contained significantly more protein, vis., $194.3 \pm 9.7 \mu \mathrm{g} /$ embryo.

The addition of insulin to the medium resulted in a significant decrease in DNA synthesis at 24 or 36 hours in all cases except the $0.1 \mu \mathrm{g} / \mathrm{ml}$ level (Fig. 3). The greatest amount of DNA synthesized occurred in the nontreated embryos at 36 hours with $15.5 \pm 1.4 \mu \mathrm{g}$ DNA/ embryo. Embryos of comparable age developing in vivo contained $29.8 \pm 2.1 \mu \mathrm{g}$ DNA/embryo. When embryos were examined histologically, mitotic cells were sparse at 24 hours, and in some instances were absent by 36 hours in both treated and non-treated embryos; they were, however, plentiful in embryos of comparable age in vivo.

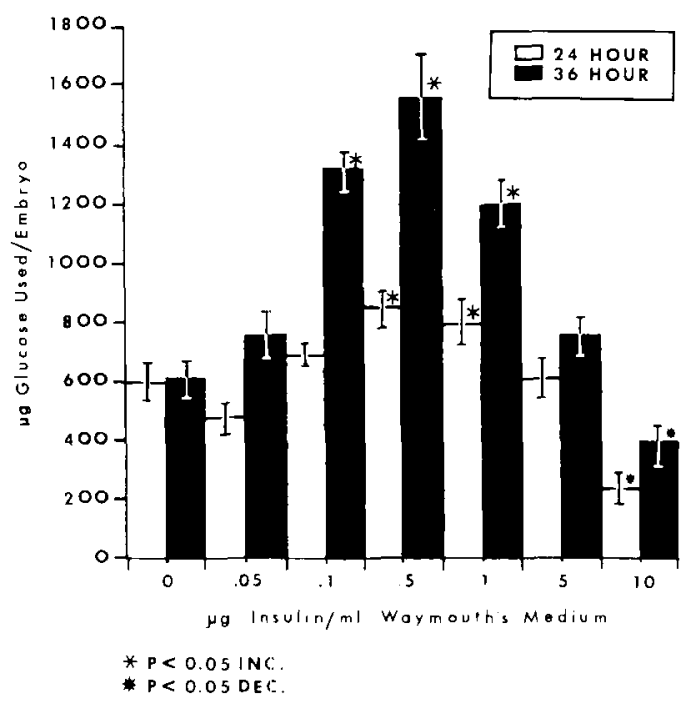

Fig. 1. Effect of insulin on glucose utilization/embryo. Vertical lines represent standard error. 


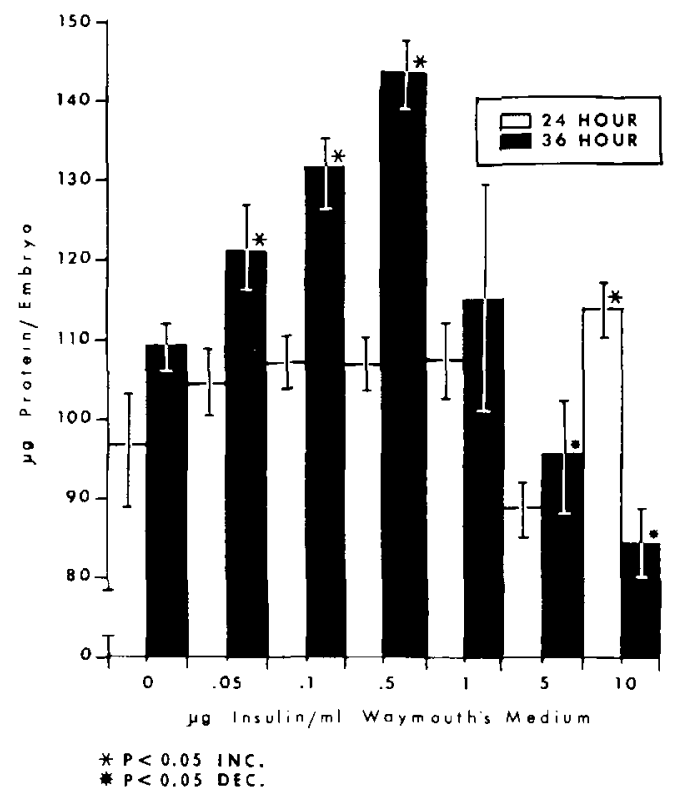

Fig. 2. Effect of insulin on protein/embryo. Vertical lines represent standard error. Ordinate broken to indicate values do not begin with zero.

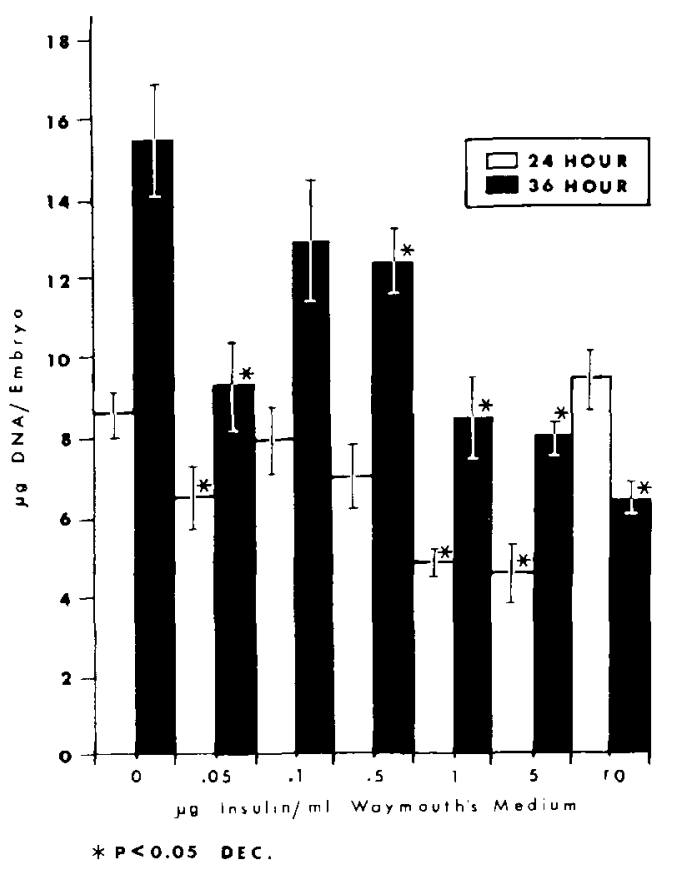

Fig. 3. Effect of insulin on DNA/embryo. Vertical lines represent standard error.

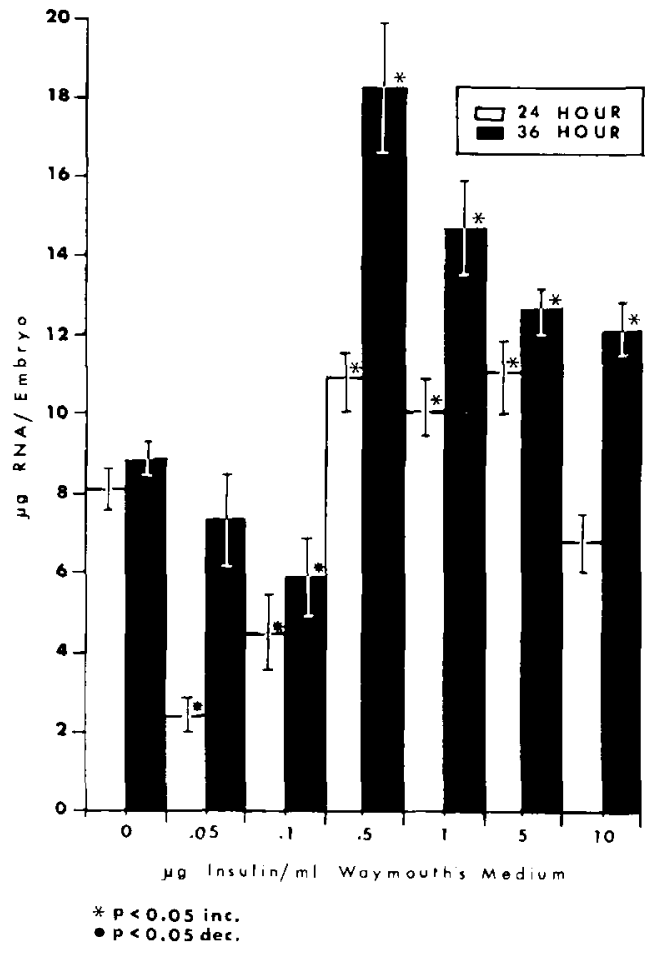

Fig. 4. Effect of insulin on RNA/embryo. Vertical lines represent standard error.

Insulin additions of 0.05 or $0.1 \mu \mathrm{g} / \mathrm{ml}$ resulted in a significant decrease in amounts of RNA present/embryo, whereas additions greater than $0.5 \mu \mathrm{g}$ insulin $/ \mathrm{ml}$ generally resulted in a significant increase in amounts of RNA synthesized (Fig. 4). A maximal response of $18.2 \pm$ $1.7 \mu \mathrm{g}$ RNA/embryo was noted at 36 hours with $0.5 \mu \mathrm{g}$ insulin/ml and differed significantly from non-treated controls.

\section{Gross morphologic changes}

Growth and differentiation of the embryo during the cultivation period, in some instances, were unaffected by the addition of insulin to the medium. At 0 hours, the mean somite number for the 206 embryos examined was $10.5 \pm 0.2$; no treated group differed significantly from any other. At 24 hours, the range in somite number for the 316 embryos examined in all groups was 15 to 25 somites, with a mean of $19.5 \pm 0.7$. The mean number of somites added did not differ significantly for any group regardless of treatment. At 36 hours, the mean for the 107 embryos examined, had risen 


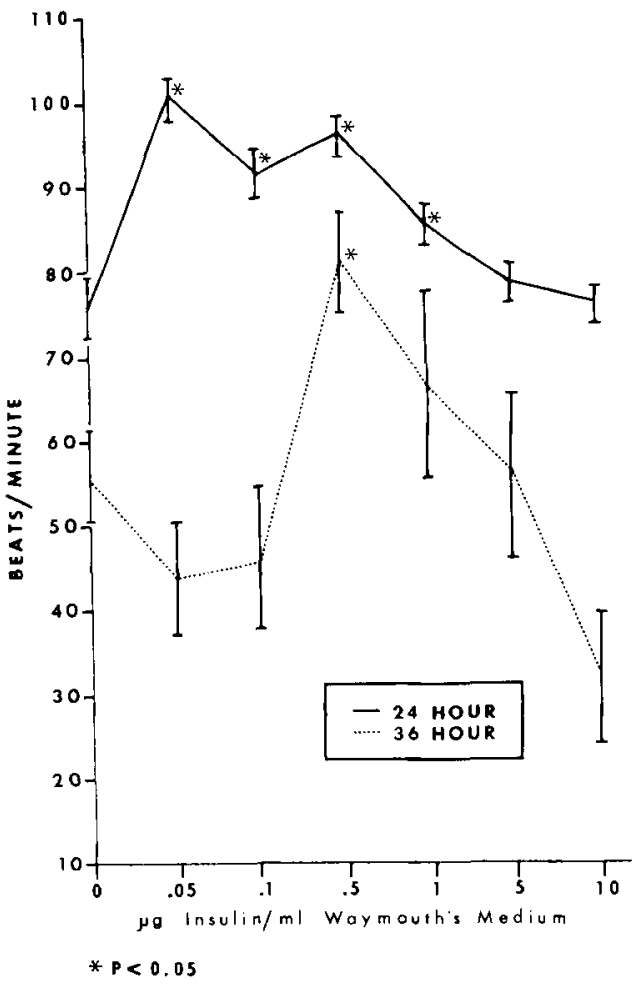

Fig. 5. Effect of insulin on heart rate/embryo. Vertical lines represent standard error. Non-treated control values represented by breaks in ordinate.

to $22.4 \pm 0.2$, but again, no group differed significantly from any other. No significant differences were noted for either the time of appearance of anterior limb buds or of closure of the anterior and posterior neuropores.

Exogenous insulin was found to affect heart rate (Fig. 5). A significant increase was noted with the four lower doses of insulin at 24 hours. At 36 hours, the only significant increase was noted for $0.5 \mu \mathrm{g}$ insulin $/ \mathrm{ml}$. It was also observed that all doses of insulin resulted in significantly fewer incidences of pericardial edema at 36 hours (Fig. 6).

\section{DISCUSSION}

The results of this experiment indicate that very high concentrations of insulin in the culture medium can alter the morphological and biochemical differentiation of mouse embryos in vitro. It does not seem likely that a greatly elevated level of insulin over that normally circulating in serum would be beneficial to the embryo in vivo. It is likely, however, that excess insulin compensates for or neutralizes cer-

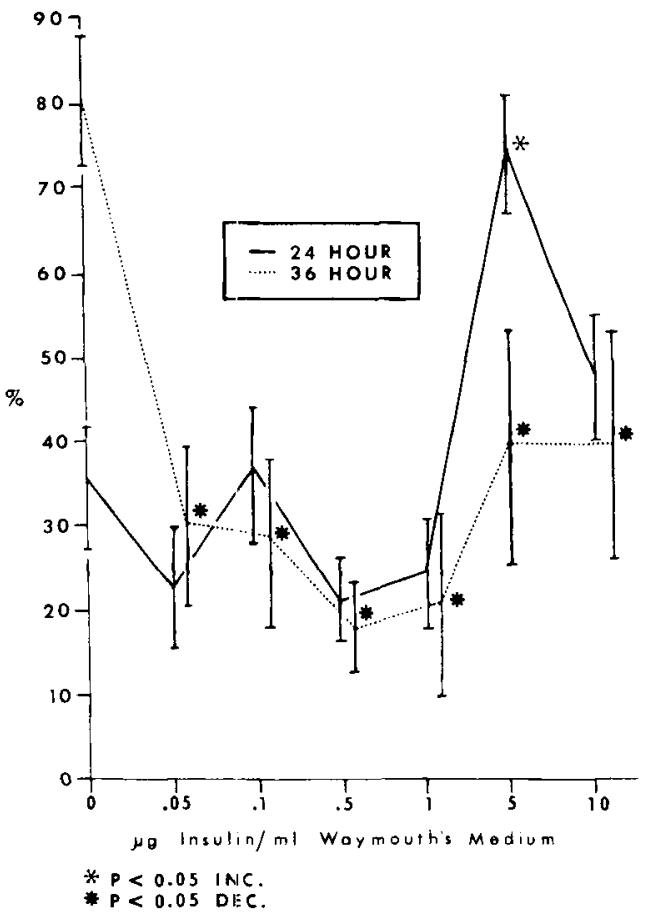

Fig. 6. Pericardial edema with insulin. Vertical lines represent standard error. Non-treated control values represented by breaks in the ordinate.

tain biochemical changes that occur in vitro, but do not appear in the environment in which development occurs normally.

These changes which may, in effect, reduce the availability of insulin to the embryo include: the binding of the hormone to glass- and plastic-ware (Cuatrecasas et al., '75; Cecil and Robinson, '75; Fischer et al., '79); conformational changes of the hormone in vitro (Roth et al., '75); and it is also possible that the presence of the hormone in excess may modulate the affinity of the insulin receptor for insulin (Roth et al., '75).

From the biochemical studies reported, the best embryonic development seems to occur in vitro with between 0.1 and $1 \mu \mathrm{g}$ of exogenous insulin/ml Waymouth's medium. Although extensive studies are lacking on insulin effects on embryonic tissue in vitro, a number of investigators have examined the effects of insulin on adult tissue. Miller and Biegelman ('67) report that as little as $0.002 \mu \mathrm{g}$ insulin $/ \mathrm{ml}$ will stimulate adult rat adipose cells in vitro to increase incorporation of amino acids. This concentration of insulin is almost 1,000 times less than 


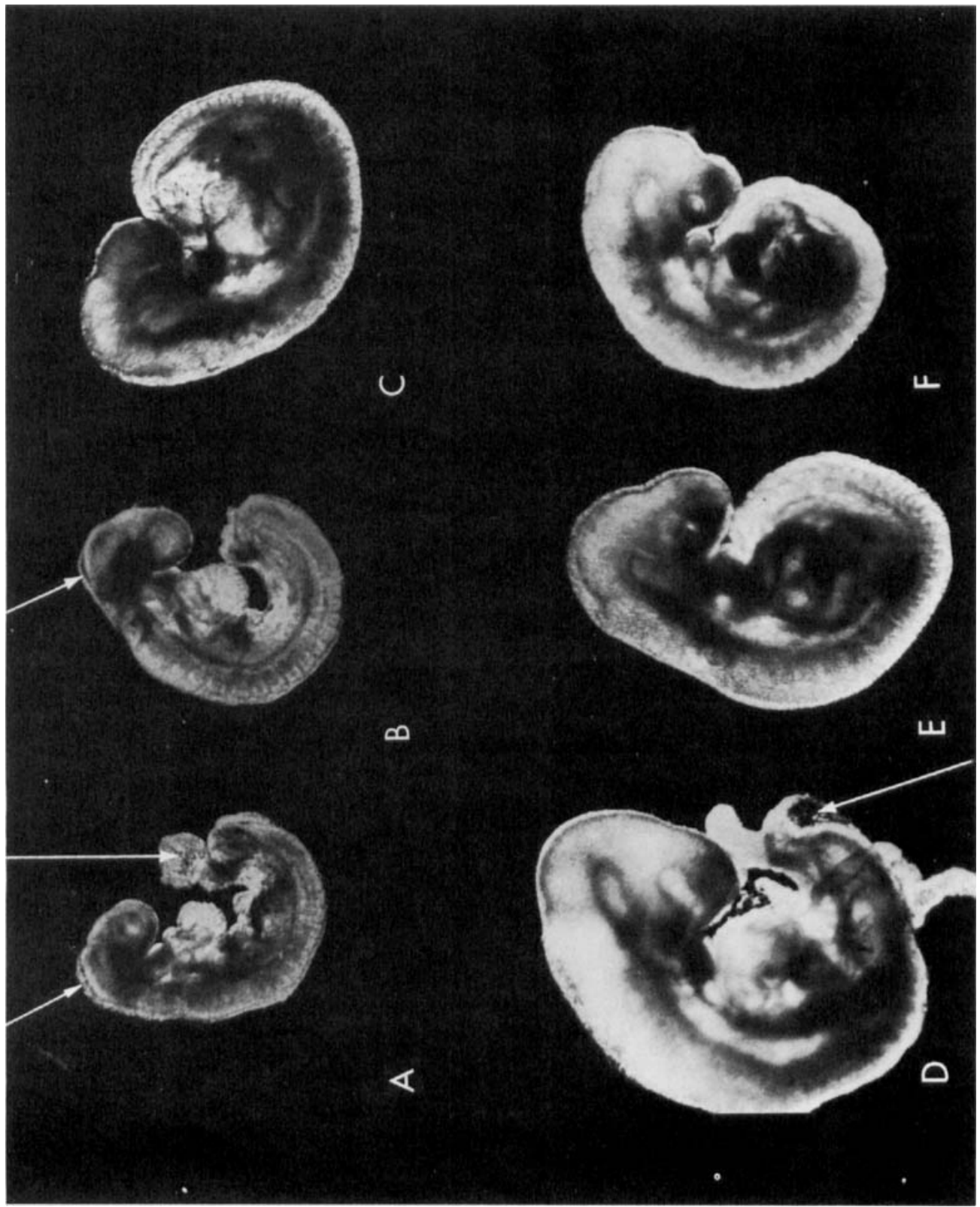

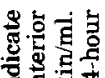

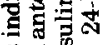

政

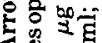

(1)

읠

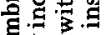

잉

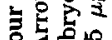

舟

is

政

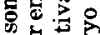

o 寻范

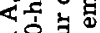

(3.

政

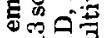

छी.

ํㅜㄹ

赔.

政

要通要

焉要哥

훙룡

ขै चี

\%

है. है

द \&

$8 \%$

证

gon

일

룽

웅응

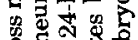

둥ํ है

过它軍

들

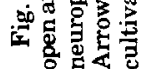



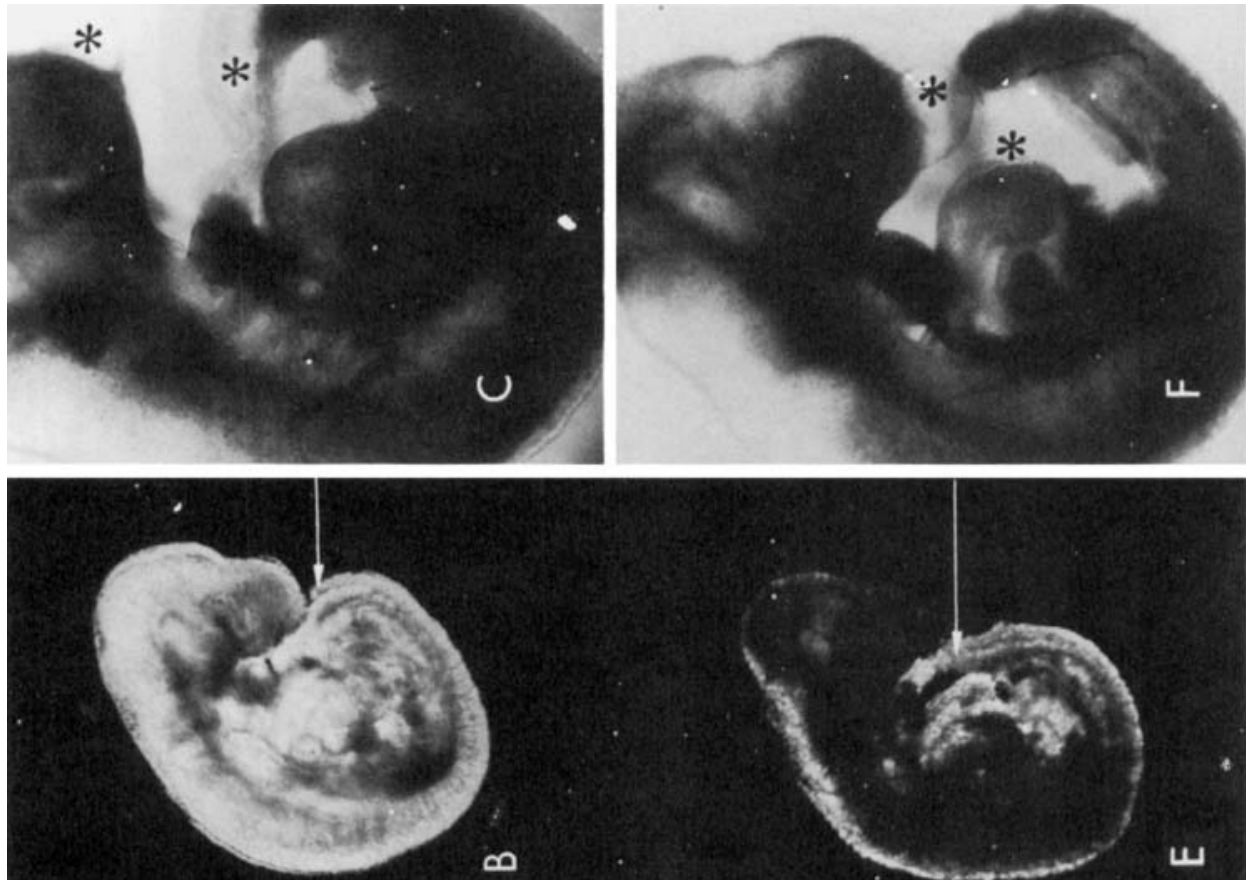

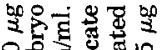
츨 돌하열 $3)_{00}=3$ 造 읭 45 घ 0 的 - 굴 \$영 $\geq$ S 5ळ 뚱요

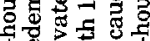

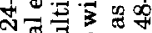
4 त्

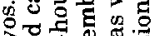
동혀

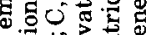

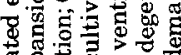

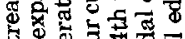
a

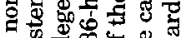
을

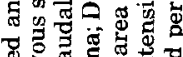
कु च

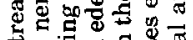

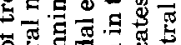

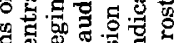
वे $\Phi$ का कo 00 T \% 등 $8 .=2$.

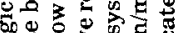
용 원

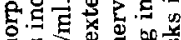
更告 o

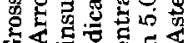
( 0.05

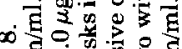

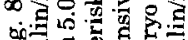

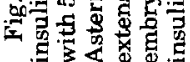


that required for maximum protein synthesis in mouse embryos developing in vitro.

The stimulation by insulin of glucose uptake in adult tissues has been shown by extensive research (review by Fritz, '72), and my study confirms the importance of insulin for the embryonic utilization of glucose in vitro.

Manchester ('67) reported that insulin may stimulate RNA metabolism in adult tissue. Because of the role of RNA in protein formation, one would also expect RNA synthesis to be enhanced. This was, in fact, confirmed in the present study of embryonic tissue.

Reddan et al. ('75) reported that insulin stimulates DNA synthesis in rabbit lens epithelium in vitro in a completely defined medium. In our experiments, this does not appear to be the case with whole mouse embryos in vitro. The addition of somites to the embryo during the cultivation periods appears unaffected by the addition of insulin, but cellular divisions may have been slowed.

When gross morphological comparisons are made (Fig. 7 and 8 ), it appears that $0.5 \mu \mathrm{g}$ insulin/ml Waymouth's medium supports optimal embryonic differentiation (Fig. 7E). At 36 hours, some central nervous system over-expansion and caudal edema are obvious in both the treated and non-treated embryos. This may be the result of the utilization of nonhomologous serum or other unknown factors. With the high dose of insulin, considerable cellular degeneration occurs (Fig. 8E). By 48 hours, extensive rostral, caudal, and pericardial edema occurs in both the treated and nontreated embryos (Fig. $8 \mathrm{C}$ and $\mathrm{E}$ ). The incidence of pericardial edema does, however, appear to be reduced by the addition of insulin.

To determine if the addition of insulin alone could allow embryonic development in a defined cultivation medium, fetal calf serum was eliminated with only Waymouth's medium and $0.5 \mu \mathrm{g}$ insulin $/ \mathrm{ml}$ present. Embryonic development could proceed for 24 hours, however, the visceral yolk sac circulation failed to materialize and the embryos soon died. Waymouth's medium without insulin did not allow development. Fetal calf serum obviously contains other substances of importance to the embryo for which further investigation is necessary.

\section{ACKNOWLEDGMENTS}

Special thanks is given to Dr. S. Pek's laboratory of the University of Michigan for assistance with the radioimmunoassay for insulin, and Dr. A.R. Beaudoin for technical advice and consultation.
This research was supported by American Cancer Society Research Grant IN-40N and, in part, by the Biomedical Research Council of the University of Michigan.

\section{LITERATURE CITED}

Cecil, R., and G.B. Robinson (1975) The "specific" binding of insulin to polythene and other materials. Biochem. Biophys. Acta, 404: 164-168.

Cockroft, D.L., and P.T. Coppola (1977) Teratogenic effects of excess glucose on head-fold rat embryos in culture. Teratology, 16:141-146.

Cuatrecasas, P., M.D. Hollenberg, K.J. Chang, and V. Bennett (1975) Hormone receptor complexed and their modulation of membrane function. Rec. Prog. Hormone Res., 31:37-83.

Esber, H.J., J. Payne, and A.E. Bogden (1973) Variability of hormone concentrations and ratios in commercial sera used for tissue culture. J. Nat. Cancer Inst., 50(2):559562.

Fischer, T.V., R.H. Kahn, W.E. Burkel, K.R. Herwig, R.C. Klann, and D.W. Vinter (1979) The effect of insulin on the maintenance of canine prostate in organ culture. Manuscript in preparation.

Fritz, I.B. (1972) Insulin actions on carbohydrate and lipid metabolism. In: Biochemical Actions of Hormones. Vol. II. G. Litwack, ed. Academic Press, New York, pp. 165-214.

Kochhar, D.M. (1975) The use of in vitro procedures in teratology. Teratology, 11:273-288.

Krahl, M.E. (1961) The action of Insulin on Cells. Academic Press, New York, pp. 202.

Lowry, O.H., N.J. Rosebrough, A.L. Farr, and R.J. Randall (1951) Protein measurement with the folin phenol reagent. J. Biol. Chem, 193:265-275.

Manchester, K.L. (1965) Insulin and protein metabolism in muscle. In: On the Nature and Treatment of Diabetes. $E$. Leibel and G.A. Wrenshall, eds. Intern. Congr. Ser. No. 84, pp. 101-115, Exc. Med. Found., Amsterdam.

Manchester, K.L. (1967) Re-evaluation of the effect of insulin on nucleic acid synthesis in muscle. Biochem. J., 105:13c$15 \mathrm{c}$.

Manchester, K.L. (1970) Insulin and protein synthesis. In: Biochemical Actions of Hormones. Vol. I. G. Litwack, ed. Academic Press, New York, pp. 216-319.

Marks, V. (1959) An improved glucose-oxidase method for determining blood, C.S.F. and urine glucose levels. Clin. Chem. Acta, 4:395-400.

Miller, L.V., and P.M. Biegelman (1967) Effects of varying concentrations of insulin upon protein synthesis in isolated fat cells. Endocrinology, 81:386-389.

New, D.A.T., and P.T. Coppola (1977) Development of a placental blood circulation in rat embryos in vitro. J. Embryol. exp. Morph., 37:227-235.

Prasad, A.S., E. DuMouchelle, D. Koniuch, and D. Oberleas (1972) A simple flurometric method for the determination of RNA and DNA in tissues. J. Lab, and Clin. Med., 80(4):598-602.

Reddan, J.R., N.J. Unakar, C.V. Harding, M. Bagchi, and G. Saldana (1975) Induction of mitosis in the cultured rabbit lens initiated by the addition of insulin to medium KEI -4 . Exp. Eye Res., 20:45-61.

Ritter, E. (1978) RNA and DNA determination on 10 and 11 day rat embryos. Personal communication.

Roth, J., C.R. Kahn, M.A. Lesniak, P. Gorden, P. De Mayts, K. Megyesi, D.M. Neville, Jr., J.R. Gavin, III, A.H. Soll, P. Freychet, I.D. Goldfine, R.S. Bar, and J.A. Archer (1975) Receptors for Insulin, NSILA-s, and growth hormone: Applications to disease states in man. In: Recent Progress in Hormone Research. Vol. 31. R.O. Greep, ed. Academic Press, New York, pp. 95-139. 